\title{
Managing Open School Units Amid COVID-19 Pandemic through the Experiences of Greek Principals. Implications for Current and Future Policies in Public Education
}

\author{
Eleftheria Spyropoulou ${ }^{1, *(1)}$ and Theodore Koutroukis ${ }^{2,3}$ (D) \\ 1 School of Psychology, Aristotle University of Thessaloniki, 54124 Thessaloniki, Greece \\ 2 Department of Economics, Faculty of Social, Political and Economic Sciences, \\ Democritus University of Thrace University Campus, 69100 Komotini, Greece; tkoutro@econ.duth.gr \\ 3 Department of Economics and Business, School of Economics, Business and Computer Science, \\ Neapolis University of Pafos, 2 Danais Avenue, 8042 Paphos, Cyprus \\ * Correspondence: elefspyr@psy.auth.gr
}

Citation: Spyropoulou, Eleftheria, and Theodore Koutroukis. 2021.

Managing Open School Units Amid COVID-19 Pandemic through the Experiences of Greek Principals. Implications for Current and Future Policies in Public Education.

Administrative Sciences 11: 70.

https://doi.org/10.3390/

admsci11030070

Received: 10 June 2021

Accepted: 8 July 2021

Published: 12 July 2021

Publisher's Note: MDPI stays neutral with regard to jurisdictional claims in published maps and institutional affiliations.

Copyright: (c) 2021 by the authors. Licensee MDPI, Basel, Switzerland. This article is an open access article distributed under the terms and conditions of the Creative Commons Attribution (CC BY) license (https:// creativecommons.org/licenses/by/ $4.0 /)$.

\begin{abstract}
The purpose of this study was to examine the experiences of primary and secondary Greek school principals, regarding the management of their school units at the beginning of the school year 2020-2021, amid the COVID-19 pandemic. A qualitative study of 57 principals was undertaken, in order to explore the following questions: (a) What were the difficulties and obstacles that principals faced during the management of the school unit from the beginning of the school year? (b) What factors helped them to manage these difficulties? Written answers were analyzed using thematic analysis. Several key findings emerged, indicating that, in general, the principals had to respond to an unprecedented crisis context, under tremendous pressure, with limited resources. They faced a variety of difficulties, both on a personal level and in the context of their professional role. They also encountered difficulties above their role, which had to do with the general impact of the extended sanitary crisis on the emotional state and perceptions of the members of the school community. The results of the research have implications for the policy that is applied in schools in the context of the COVID-19 pandemic.
\end{abstract}

Keywords: school management; principals; leadership; COVID-19; Greece; public education

\section{Introduction}

By the time this article is written, the COVID-19 pandemic continues its uncontrolled trajectory all over the world. This virus has rearranged all aspects of our socio-economic and political life (Vlados 2020b). It has created a passage to a new phase of global evolution (Vlados 2020a). One year after the pandemic outbreak, and despite the feelings of hope that the beginning of vaccinations raised, the number of new instances and the number of deaths globally, are leaving no space for complacency. The tight isolation measures that were suddenly taken to mitigate the viral spread and contagion of COVID19 , violated basic psychological needs, such as competence, autonomy and affiliation (Ryan and Deci 2000). The pandemic has had a serious impact on mental health, exacerbating preexisting psychopathology (Adhanom Ghebreyeseus 2020). Although further research is needed on the effects of COVID-19 on mental health (Mahase 2020), there are valid fears about the increase in depression, anxiety, and substance abuse (Galea et al. 2020; Liu et al. 2020). Domestic violence is reported to have already significantly increased globally (Graham-Harrison et al. 2020). Moreover, the economic impact of this sanitary crisis has been severe, and is expected to worsen, especially for those that were already financially vulnerable (Policy Scotland 2020; UNISEF 2020). It has been widely documented that children from low socioeconomic environments are at greater risk for poor physical and mental health (e.g., Klipker et al. 2018; Paleologou et al. 2018; Schneider et al. 2017). Poverty also 
increases the risk of exploitation, maltreatment and child abuse, as has occurred during previous public health emergencies (Neria et al. 2008; UNISEF 2020).

At the beginning of the pandemic, Greeks were already experiencing declining incomes, unemployment, and a general feeling of insecurity, due to the financial crisis the country has been facing over the last twelve years. Health and education had already suffered major cuts in their funding (Dassiou 2015), while, at the same time, adolescents' mental health problems were found to have increased during the recession, especially those from the most vulnerable socio-economic groups (Paleologou et al. 2018).

\subsection{COVID-19 Pandemic and Education}

The COVID-19 outbreak is characterized not only as a danger to social and economic cohesion, but also as a threat to education and training systems' stability and sustainability (Lifelong Learning Platform 2020), which have been disrupted as never before (United Nations 2020). According to the European Commission, distance learning is expected to negatively affect students' achievement, due to the reduction in time devoted to learning, the decrease in motivation for school tasks, the changes in the way of interacting with classmates, and the mental burden to students, caused by quarantine (Di Pietro et al. 2020). The danger of falling behind both cognitively and socio-emotionally is greater for younger children, children from less-advantaged backgrounds, and students with disabilities (Di Pietro et al. 2020). Learning losses "threaten to extend beyond this generation and erase decades of progress" (United Nations 2020, p. 2), widening the social gap and inequality. Moreover, the current literature highlights that the COVID-19 pandemic has severely injured students' sense of security (Liu and Doan 2020), putting them at risk for post-traumatic stress and other mental problems (Fegert et al. 2020; Liu et al. 2020).

Under this spectrum, the need for open schools is urgent, and aligns with the measures that countries have to take to contain the pandemic (United Nations 2020). The available evidence from previous severe epidemics, in which restrictive measures have been implemented, underscores the importance of returning to school for many children, even under different circumstances (Shultz et al. 2016; Van Bortel et al. 2016). The return of students to their daily routines contributes to the consolidation of stability and continuity, and is associated with reduced traumatic stress after an epidemic condition (Van Bortel et al. 2016).

In that sense, special attention has been given, by many countries, to the reopening of school units for the new session 2021-2022, and the compassionate transition and reconnection of students and all members of school communities (e.g., Crawford et al. 2020; Halladay Goldman et al. 2020; Hatzichristou et al. 2020). The protection of already vulnerable members, management of students and teachers with possible positive diagnoses, and care to avoid stigma had to be the priorities (UNISEF 2020). Particular attention should also be paid to students in major transitions, such as those entering pre-school education and those moving from primary to secondary education (British Psychological Society 2020; Evangelou et al. 2008). Principals and educational personnel were encouraged to implement strategies, such as establishing routines, good communication, and student support, that would help the strengthening and restoration of a learning environment that is "wounded" (Halladay Goldman et al. 2020).

However, with the opening of school units on the 14th of September 2020, Greek principals, teachers and students had to respond to an unprecedented experience and school routine. School leaders and their staff faced the huge responsibility of managing and organizing school units according to a set of strict health protocols (with basic measures including the total use of facemasks, physical distance, and hand disinfection), in order to reduce potential viral transfer among the members of the school community.

The available studies on past community crises underscored the significance of decisive, open and clear leadership in the enhancement of resilience in schools (Education Review Office 2013). In order for schools to respond effectively to critical situations, the principals' role is crucial in providing guidance, promoting a positive school climate, and in empowering teachers (Day and Sammons 2014). "In the current context of 
uncertainty, chaos and change, the pressure on leaders to stay in the role and to succeed has never been greater" (Stone-Johnson and Weiner 2020, p. 371).

\subsection{Effects of Pandemic on Principals and Teachers}

The available research on the effects of COVID-19 on the educational community mostly concerns the spring months. By the time this article is written, the literature on open schools' reality from autumn onwards is scarce. The sudden and urgent entry and adaptation to new technologies for virtual learning, and the shifts between inperson and online teaching, as unfolded in the spring, caused confusion and great mental burden to teachers and school leaders (Anderson et al. 2020; Argyropoulou et al. 2021; Brackett and Cipriano 2020; Educational Institute of Scotland 2020). They faced drastic disruptions to the routine of their job, their schedule, and their presence in students' lives. Teaching and learning became factors of stress, with scarce equipment and digital competences, in many cases, and with principals trying to find solutions to enable students to continue to learn and families to stay connected to the school community (Anderson et al. 2020; Argyropoulou et al. 2021; Educational Institute of Scotland 2020).

Concurrently, from the beginning of the pandemic, principals faced the same challenges as anyone else, which were trying to find balance in the new ways of living and working, and having to manage their own fears and uncertainties. Anxiety, fear, worry, shock, and sadness were the most-mentioned feelings of more than 5000 teachers and school leaders in the United States at the end of March 2020 (Brackett and Cipriano 2020). Anxiety mainly had to do with the fear of being infected with COVID-19, either themselves or their staff, students and their family, as well as with the time management in relation to personal, family and professional needs. Principals experienced heightened stress while working remotely from home, facing great difficulty to "break from work", an inability to separate the working day from their personal life, and spending numerous hours at night and on the weekends trying to manage their schools and take care of all members of the school community (Anderson et al. 2020; Brackett et al. 2020; Educational Institute of Scotland 2020). Limited contact with colleagues, inadequate access to resources, and poor communication from senior managers and local authority leads, were extra pressing issues for principals while they were working from home (Educational Institute of Scotland 2020). In many cases, especially in low-income contexts, the principals' responsibilities extended beyond the strictly "academic" work, setting, as a priority, the basic needs, and also the health and psychological needs of the members of their school community and, only later, the instructional matters (Anderson et al. 2020; Kaul et al. 2020). Moreover, the available research highlights the difficulty of educational staff to monitor pupils' compliance with the measure of physical distance, when schools were open, as well as the difficulty of children, especially those in primary school, to follow this measure (Di Pietro et al. 2020; Educational Institute of Scotland 2020).

Consequently, principals and teaching staff began the school year already overwhelmed by the previous period. They have been asked to return to the classroom and work in potentially unsafe conditions. This had the result of causing some teachers to exhibit psychological symptoms (such as frustration and anger) that characterize frontline health care workers (Teach for America 2020). It is argued that educators were already facing declining confidence and enormous stress, and the pandemic has only deepened that reality (Brackett and Cipriano 2020). Due to the unpredictable nature of the pandemic, and the feeling that there is no end, teachers are in danger of massively exhibiting an insidious type of burn-out that is difficult to overcome (Teach for America 2020). As teachers' mental health affects students' learning progress (McLean and Connor 2018), in view of the reopening of schools in the fall, principals were urged to focus on the mental health and wellbeing of their staff, finding ways of supporting and maintaining a strong sense of community, despite the adverse circumstances (Crawford et al. 2020; Green and Bettini 2020). 


\subsection{Principals' Sources of Support}

Although much of the literature supports that the COVID-19 pandemic has caused an accumulation of risk factors for mental health, displacing the protective factors (Gruber et al. 2020), history suggests that resilience and recovery prevail in the long term, "even for those most directly impacted or those on the frontlines of the outbreak" (PeConga et al. 2020, p. 47). The available research from the spring months shows that principals who had already built a culture of trust among the members of the school community were able to leverage the existing structures to give better support (Kaul et al. 2020). Maintaining strong connections with teachers, staff, students and parents proved to be crucial in managing through the pandemic (Brackett et al. 2020). Collaboration and communication between the district and school, district support to principals in solving problems, possibility of autonomy, as well as availability and access to information, infrastructure and services, were factors that helped principals to manage crisis in the school context (Hubbard et al. 2020). Personal characteristics and skills, such as empathy, advocacy, optimism and hopefulness, were also highlighted by the principals, in the spring surveys, as helpful factors in taking care of oneself and others (Anderson et al. 2020).

\subsection{Aims}

The research was conducted at the beginning of the school year 2020-2021, in order to shed light on the experiences of principals in relation to the management of open school units under the unprecedented health crisis context, and the strict health protocols that had to be implemented in school life, due to the pandemic. Due to the scarcity of relevant contemporary research, the findings may enrich the literature on the problems principals faced when managing open school units amidst the COVID-19 pandemic, as well as on the effective management practices and helpful factors that can contribute to principals' resilience. The following research questions framed the investigation:

1. What were the difficulties and obstacles that principals faced during the management of the school unit from the beginning of the school year?

2. What factors helped them to manage these difficulties?

The study identified the difficulties, obstacles and needs of Greek principals, but also effective practices in relation to the management of open school units amidst the COVID-19 pandemic. The findings could be used from local and state authorities for the planning and implementation of interventions, policies and strategies to support and empower schools, principals and educational staff.

\section{Materials and Method}

\subsection{General Methodology}

The study follows the qualitative methodology. It was conducted in the frame of planning a training seminar for principals, with the aim of strengthening and supporting them in their role. In that sense, it is a needs assessment study. We aimed to capture emerging problems and practices in real time, trying to highlight existing ways of management and needs of school leaders at this particular social and historical moment. We used an electronic questionnaire that included an introductory note, three open-ended questions, corresponding to the research aims, and two demographic questions, concerning the gender and the educational level of the participants. We used open-ended questions, as well as minimal demographic data, with the aim to help principals to feel as free as possible to express and reflect their experience, while ensuring their anonymity. More specifically, the three open-ended questions were as follows: What are the main difficulties you faced in managing the school unit from the beginning of the school year? What are the major obstacles you have faced in trying to manage these difficulties? What helped you manage these difficulties? 


\subsection{Participants}

The study was addressed to principals of public primary and secondary schools in Western Thessaloniki. Thessaloniki is the second largest city in the country, located in Northern Greece. An email was sent to all kindergartens, primary and secondary schools located in a district of six municipalities that conclude urban, suburban and rural communities. Principals were invited to participate voluntarily in the survey by clicking on a link in the text of the email, which would give them access to the questionnaire. They were also informed that their responses would be anonymous. Due to the unprecedented situation and the lack of relevant research, all school leaders were considered as information-rich cases. Fifty-seven principals (26 primary, 31 secondary) responded (percentage $15 \%$ of the total invited). Twenty-nine were women and 28 men. Data were collected during the fourth week from the start of the school year 2020-2021 and more particularly between the 5th and the 9th of October.

\subsection{Process of Analysis}

Principals' written answers were analyzed using thematic analysis, a method widely used in qualitative research to identify, analyze and report patterns (themes) of experience and reality of participants. The advantages of this analysis include the theoretical freedom and flexibility, which allow a rich and detailed account of data (Braun and Clarke 2006). Analysis was conducted through a repetitive process of active reading, coding, identifying patterns of common experience, writing and reflecting.

The analysis followed a combination of an inductive and deductive approach (Fereday and Muir-Cochrane 2006); while it was conducted in relation to the research questions, coding and identification of themes were strongly linked to the data from the set of questions, following the "bottom-up" way (Boyatzis 1998).

Analysis was conducted by the two researchers who worked in parallel and independently, with a high degree of agreement in coding and exporting of key issues. The analysis resulted in four main themes, in relation to the research questions, which were as follows: (a) health protocols in school, (b) physical and mental burden, (c) lack of resources, and (d) strengths. The main themes and the key issues they include (see Table 1) are discussed below.

Table 1. Main themes and key issues.

\begin{tabular}{cc}
\hline Main Theme & Key Issues \\
\hline Health protocols in school & Difficulties in implementation and adherence \\
& Disruption of educational and pedagogical work \\
Increased responsibilities and workload \\
Physical and mental burden & Stress and fear of COVID-19 infection \\
Lack of resources & Material and human resources \\
Strengths & Personality and skills \\
& Microsystem \\
\hline
\end{tabular}

Source: Procession from secondary data.

\section{Results and Analysis}

\subsection{Health Protocols in School}

3.1.1. Difficulties in Implementation and Adherence

In general, all the principals faced great difficulty in "organizing the school unit" according to health protocols. In order to comply with the contingency measures, and to avoid crowding, the principals had to make "changes to the timetable" and the familiar routine of the school. The "management of school classes" was a difficult task for many principals, as they had to make provision for "different breaks, continuous teaching hours and an increase in teachers' on-call time". Social distancing and the catholic use of the mask troubled all school principals. A primary school principal characteristically stated that the main difficulty was "the adaptation of our students to the compulsory use of the mask and especially to keeping distances 
outside the classroom". Several heads of kindergartens cited "[...] the young age of kids in managing measures" as an obstacle, noting that "a lot of time was spent in learning to use the mask". Many principals, of all grades, also highlighted that "The large number of students per class" created significant difficulty in complying with the measures. As a school leader of a primary school commented, "protocols are impossible to be applied exactly".

Moreover, several principals faced the "refusal to comply with the measures" by some members of the school community, the "suspicion towards the instructions", and "the doubt about the existence of COVID-19 pandemic". The heads of kindergartens and primary schools reported that there were "Parents who refused to bring their kids to school". In some cases, there were "disapprovals of teachers for the school mode". The effect of these phenomena was, in some cases, the creation of "tension in the relation with parents, students and colleagues". In one case, a principal of a school based in a Roma community reported that he had to deal with the "reaction of the local community against the measures".

\subsubsection{Disruption of Educational and Pedagogical Work}

The majority of principals pointed out that "a lot of time is spent in keeping to the protocols at the expense of the educational process". Some heads of kindergartens, notably, pointed out that "the measures are contrary to pedagogical practices of the kindergarten". As one of them explained, "stable groups in the kindergarten make it difficult to carry out the curriculum and make the implementation of plenum impossible". In another case, a kindergarten's head expressed her sadness, because, according to her words, "I cannot hug them and make them feel safe and loved". Moreover, most of the principals highlighted that "the use of mask is terribly annoying and makes teaching and learning process difficult". More particularly, it is mentioned that "[...] there is difficulty in communicating with students" as well as "bigger effort is needed to be understood and to understand, because of the mask". The consequence was that "teachers feel exhausted", "[...] they are forced to speak louder, they do not breathe normally and when they return home, they feel more tired than in previous years". Another effect that fewer principals pointed out was that "only frontal teaching is now adopted". Five principals commented that, due to the restrictive measures, there is "[...] particular difficulty in conducting the lesson of gymnastics".

\subsection{Physical and Mental Burden}

\subsubsection{Increased Responsibilities and Workload}

With the start of the school year, principals of all grades were called upon to carry through with a huge amount of work and responsibilities, extra of the usual, in a frame of ambiguity. As a principal of secondary school stated, "Many issues that had to be handled in a short time, demands for immediate response, requests from the ministry for issues that have not been prepared and many unanswered questions". Lots of school leaders talked about the "huge amount of bureaucracy, circulars and announcements, extra this year relating to coronavirus that had to be read and discussed. Many of them had contradictory statements that needed clarification". As a primary school's principal commented "[... ] valuable time is lost in telephone communications". At the same time, due to the prohibition of parents to enter the school premises, principals had to inform and guide parents via the Greek School Network and school's website. This condition created, on top of the additional workload, great difficulty to many principals, because, as a head of kindergarten noted, "Impersonal communication does not bring the results we would like". Additionally, some principals expressed the feeling of "[...] great responsibility about the behavior of colleagues". Most school leaders referred to "excessive pressure and fatigue", with one noting "[... a lot of work at the expense of my family".

\subsubsection{Stress and Fear of COVID-19 Infection}

A significant number of principals identified, from the beginning of the school year, the management of the anxiety and fear in relation to coronavirus as a major difficulty. A principal of a high school characteristically made the following comment: "there were teachers who were afraid to come in contact with colleagues but also with students and were thinking 
about how to get to the classroom. And it was normal because almost everyone had a problem related to COVID-19 such as: belonging to vulnerable groups themselves or someone of their own, they had elderly parents, a child with a problem etc." Some school leaders shared "the personal fear for the health of mine and of my intimates". Moreover, another principal of a primary school reported serious concern and "[...] difficulties regarding the management of sick students in general [...] what is predicted by the protocol and if parents will cooperate". The "ambiguity of what will happen even the same day" has provoked particularly negative feelings to some principals, to the point of feel like "[... laboratory animals" according to one's words.

\subsection{Lack of Resources}

\subsubsection{Material and Human Resources}

A significant barrier for some principals, in managing the school unit amidst the pandemic, was the large number of students per class, in conjunction with the lack of appropriate premises. A kindergarten's leader made the following statement: "there are 25 children in a classroom of 42 sq.m. There is no other multipurpose room". A small number of principals of all grades mentioned "[...] incomplete maintenance of the school building". In one case, a secondary school principal quoted the following: "[a main difficulty was] the condition of the building, with classrooms in the basements, unsuitable for teaching in the current conditions". A lack of financial resources is also cited as a major obstacle in effectively managing crisis in the school context. Few principals talked about "the technological inadequacy of public schools", the "[...] weak network", and "the lack of computers on the part of the students". One principal referred to "[...] non-existent masks and antiseptics". In addition, a small number of principals had to manage the lack of personnel. For example, a secondary school principal mentioned "lack of cleaning staff", while a principal of a primary school with a refugee reception class highlighted the following: "[...] and this year the NGO does not provide interpreters".

\subsubsection{Support from Superior Authorities}

To this point, it is important to mention that in Greece, both principals and school staff in general act according to the directions of the Ministry of Education, while the school facilities are under the responsibility of local municipalities.

Some principals of all levels of education, mainly those who faced problems with premises and equipment, pointed out the "negligence of the authorities". As a secondary school principal stated, "the official bodies from which we asked for a solution or answer to questions or problems, e.g., the Directorate and especially the municipality could not help".

There were also some principals who complained about the lack of adequate information from superior authorities, concerning the management of the situation. A principal of a secondary school clarified the following: "conflicting information and practices regarding prevention and treatment of COVID-19. There was a need for immediate, timely and valid information to all". According to a principal of a primary school "information material was sent but we would also prefer an in-person update or even remote". The need for intimacy is expressed in the quota of a kindergarten leader, as follows: "I feel alone, [...] with instructions and encyclicals the problems are not solved". From another spectrum, a primary school leader argued that "it [the management of the situation] requires clear legal framework connected with the reality of schools".

\subsection{Strengths}

\subsubsection{Personality and Skills}

Struggling to manage the unprecedented conditions, the principals mobilized all their personal and social skills, in order to sail in the storm. A calm attitude, determination, as well as "patience and perseverance in following the rules", are referred to, by many principals, as helpful factors in managing the situation. "The awareness that adapting and moving to new conditions requires a reasonable amount of time" helped another primary school principal. In addition, several school leaders reported that their good mood and tolerance helped 
a lot, as well as "understanding the other's position and trying to get in his shoes", according to a secondary school leader. Moreover, many principals noted their strong willingness to communicate and discuss with all the members of the school community "[...] in order to resolve any questions and understand how we should deal with this situation". Some also referred to their persuasion. Furthermore, many principals tried to foster a sense of connectedness "[...] by daily and methodical information of colleagues about the situation, sending them videos, links to useful material and updates". Likewise, they tried to keep in touch with parents, through telecommunications. Few principals refer to the good organization, the distribution of tasks, and the good coordination, as personal skills that helped them manage the crisis. Few principals also stated that their experience in managing the school unit was a factor that helped a lot. One principal also mentioned his relevant training.

\subsubsection{Microsystem}

Many principals referred the support and help they received from the teachers of their school, but also from parents. A secondary school principal highlighted "the conscientiousness and effort of the members of the school community". Principals also pointed out "[...] the immediate response", "[...] their good mood", "[...] the tolerance", and the effort of their colleagues to find solutions. Moreover, some school leaders remarked that a helpful element in dealing with difficulties was "the good cooperation between teachers", as well as "the pre-existing good climate and excellent relations with colleagues". Although good cooperation with parents was mentioned to a lesser extent, it seems, in cases where it occurred, to have been particularly helpful. A head of kindergarten also stated that she received significant support from her family, while a primary school principal quoted that he was helped by "the good personal life and good company with intimates". In two cases, principals received help from public service representatives to solve school problems.

\section{Discussion}

In this study, we examined Greek school principals' experiences in the management of school units at the beginning of the school year 2020-2021 amid the COVID-19 pandemic, in relation to the difficulties and obstacles they encountered, as well as their sources of support. Several key findings emerged, indicating that, in general, the principals had to operate in an unprecedented crisis context, under tremendous pressure, with limited resources. Under this condition and according to the findings, they were not ready enough, and they were not aware enough (Lifelong Learning Platform 2020). They faced a variety of difficulties, both on a personal level and in the context of their professional role. They also encountered difficulties above their role that had to do with the general impact of the extended sanitary crisis on the emotional state and perceptions of the members of the school community.

\subsection{Difficulties and Obstacles in Managing Schools at the Beginning of the School Year}

According to the analysis, school leaders as a whole accepted the responsibility to implement the sanitary protocols, and took it very seriously, advocating for the protection of the physical health and safety of the entire school community. Organizing the school unit according to the protocol was a particularly painful process, not only because the daily routine of school had to be changed, but mainly because they had to care about the adaptation of both teachers and students to these measures, but also for their proper observance.

The catholic use of facemasks and the social distancing of two meters, especially during breaks, were reported as significant difficulties by the principals, especially in relation to younger pupils, which is in agreement with previous research (Di Pietro et al. 2020; Educational Institute of Scotland 2020). This fact, combined with the large number of children per class, made it, in some cases, impossible for the protocols to be applied exactly. It should be noted that in Greece, the maximum number of students per class amounts to 25 , with a minimum of 15 . Moreover, the majority of the principals pointed out that social distancing and the use of a mask in school greatly disturbed the educational process 
and the pedagogical work in general. They referred to difficulties in communication with students, in delivering lessons, and in carrying out the curriculum, with frontal teaching as the only possible practice. It turned out that the measures had a serious impact on the pedagogical practices of kindergarten, while limiting the ability of kindergarten teachers to provide emotional support to the children. The suspicion of some parents and teachers of the containment measures, as well as the existence of refusals to comply with them, further complicated the work of the principals, arousing, in some cases, tension in these relationships. At the same time, ministerial requests for immediate response, increased bureaucracy, and contradictory statements of circulars, absorbed valuable energy, making it difficult for school leaders to find the time to solve "adaptive challenges", which would require them to "build new ways of being and responding beyond the current repertoires of available know-how" (Heifetz et al. 2009, p. 2). Increased responsibilities, excessive pressure, and fatigue, at the expense of personal life, were reported by the majority of school leaders, highlighting the continuing physical and mental burden they have been experiencing since the onset of the pandemic, as evidenced by previous surveys (Anderson et al. 2020; Argyropoulou et al. 2021; Brackett and Cipriano 2020; Educational Institute of Scotland 2020). Concurrently, the fear of coronavirus, and the ambiguity of what will happen even the same day, as experienced uninterruptedly since spring (Brackett et al. 2020), have been shown to have affected the school atmosphere, interpersonal relationships, and even the desire of some teachers to perform their educational duties. The finding that some may feel like "laboratory animals", as expressed by one principal, indicates the existence of particularly negative emotions, which supports the literature that states teachers, nowadays, exhibit psychological symptoms that characterize front line health care workers, being in danger of exhibiting an insidious type of burn-out that is difficult to overcome (Teach for America 2020).

Due to the lack of administrative and financial autonomy of Greek schools, the principals who had problems with inappropriate classrooms, incomplete maintenance of the school buildings, and technological and material deficiencies or lack, in some cases, of auxiliary staff, turned for help to local and state authority services. For some school leaders, this support never came. In only two cases, public service representatives are reported as sources of help in solving school problems. According to previous studies, district support to principals in solving problems, and access to information, infrastructure and services were factors that helped the principals to manage crisis effectively (Hubbard et al. 2020). There were also principals who reported that they were feeling as though they were left alone, as they needed clearer information and guidance, in a more intimate way, from their supervisors, regarding the management of the situation. This data supports the finding that school leaders need to feel valued and supported by their supervisors, via clear goals and expectations, transparency, and frequent communication, which are factors that can mitigate their anxiety (Brackett et al. 2020).

\subsection{Helpful Factors in Managing Difficulties}

Having to manage school units in this crisis context, the majority of the principals relied largely on their own forces and strengths, recruiting their personal and social skills, as well as their experience and knowledge in school management. Patience and perseverance, good mood and empathy, and the willingness to communicate and discuss helped school leaders to cope and keep control of the situation. A good mood, optimism, and hopefulness were also highlighted by the principals in the spring surveys, as helpful factors in taking care of oneself and others (Anderson et al. 2020). This mindset of the principals advocates the claim that "when ordinary sources of reward and fulfillment are cut off, prosocial acts of tolerance, support, and kindness can strongly buffer against negative effects" (PeConga et al. 2020, p. S48).

Several principals stressed the usefulness of their effort to foster a sense of connectedness, by regular and methodical updating of teachers and parents about the situation. The principals' efforts to maintain a sense of community was also highlighted in the spring surveys (e.g., Anderson et al. 2020; Argyropoulou et al. 2021). This finding sup- 
ports the contention that maintaining strong connections with the members of the school community plays a critical role in managing through the pandemic (Brackett et al. 2020; Duffield and $\mathrm{O}^{\prime}$ Hare 2020). Staying informed is also a crucial factor in promoting resilience (Hubbard et al. 2020).

The members of the microsystem, mainly colleagues, parents, to a lesser extent, and, in some cases, family and friends, supported principals in these demanding conditions. The finding that good cooperation between teachers and pre-existing good climate and relations with their colleagues played an important role in dealing with adversities, supports previous research that has indicated that principals who had already built a culture of trust, were able to leverage the existing structures to better support their school communities (Kaul et al. 2020). The important role of social support and positive relationships in dealing with adversities (Feeney and Collins 2015) is also confirmed.

\subsection{General Conclusions}

The findings indicate that, during the first month of the school year 2020-2021, the principals prioritized the safety and physical health of the school community, staying focused on instructional/regulatory matters rather than psychological needs, which is in opposition to the research findings of the spring months (e.g., Anderson et al. 2020; Kaul et al. 2020). Although the promotion of educators' wellbeing, response to students' emotional needs, and collaboration with parents are referred as key concepts for the compassionate and effective transition to school after school closures (Crawford et al. 2020), a lack of resources, exhausting work rhythms, fear of infection, difficulties in communication and in approaching children due to the restrictions, and impersonal contact with parents, proved, in the present study, to have been major obstacles in achieving these goals, at least during the first period of schools' operation.

As the evolution of the COVID-19 pandemic is still unpredictable, and the conditions so far require the educational process to alternate between virtual and school classrooms, these obstacles seem quite difficult to overcome; this is unless principals and teaching staff receive appropriate recognition and support to maintain resilient and meet their extremely important social role, which is to prepare children and young people cognitively and emotionally for the struggle of life. Principals cannot decide whether or when schools will open and close, "but can be loud and clear about what matters in the process" (Stone-Johnson and Weiner 2020, p. 372). The present study could be utilized in this direction. According to the findings of this study, timely, frequent and clear information and guidance from supervisors are found to be extremely important for the principals to manage open school units amidst the pandemic, at the beginning of the school year. Help from local and state authority services, for material, infrastructural and financial resources, is also crucial. A smaller number of students per class and fewer hours per teacher, especially for classes with younger children, could potentially help implement sanitary measures more effectively, and reduce teacher exhaustion. Strengthening the school units with more teaching and support staff would help to relieve both the teachers and principals of the increased tasks. Lifelong mentoring and counseling services, to support the effective communication and conflict resolution of school staff, could enhance the good cooperation between teachers and the good climate that is found to play an important role in dealing with adversities. Support from mental health professionals, in managing stress, mental exhaustion, and fear of getting sick from corona virus, is absolutely necessary, according to the results. Coaching and training for principals and school staff, in managing stress and workload, as well as in crisis and trauma management, would enhance their preparedness and resilience in managing health-threatening situations.

\section{Conclusions}

This study identified the difficulties, obstacles, and needs of Greek principals, but also effective practices in relation to the management of open school units, amidst the COVID19 pandemic. Many findings are consistent with previous research, while others expand 
the knowledge about the type of problems faced by school principals at the start of the school year 2020-2021. Important issues that emerged from this research are the disruption to the educational process, due to sanitary measures, and their impact on pedagogical practice, especially of kindergarten, the difficulty of younger students to respond to the measures, and the feeling of many principals that they were left alone from superior authorities. The results could be used to plan and implement interventions, policies and strategies to support and empower schools, principals and educational staff, in order to respond effectively to their crucial preventive role, both in the current and future crises. The research could be repeated in different time periods, in order to identify the evolution of the difficulties, but also the ways of management over time. Further research could detect the effect that factors such as the socio-economic level or geographical location of a school community may have on the needs and difficulties of the principals. Research should also focus on the training needs of principals, in order to develop targeted interventions for their empowerment. The outcomes of studies that focus on principals' effective management practices could be used in training programs, as evidence-based helpful strategies in times of crisis and in general. Stress management, as well as relationship management, were key needs that emerged in this study. Although, the need for external support, and particularly from superior authorities and mental health professionals, is unquestioned.

Author Contributions: E.S. and T.K. contributed equally to this work. Both the authors have read and agreed to the published version of the manuscript.

Funding: This research received no external funding.

Institutional Review Board Statement: Not applicable.

Informed Consent Statement: Informed consent was obtained from all the subjects involved in the study.

Data Availability Statement: The data presented in this study are available on request from the corresponding authors.

Conflicts of Interest: The authors declare no conflict of interest.

\section{References}

Adhanom Ghebreyeseus, Tedros. 2020. Addressing mental health needs: An integral part of Covid-19 response. World Psychiatry 19: 129-30. [CrossRef]

Anderson, Erin, Sonya Hayes, and Bradley Carpenter. 2020. Principal as Caregiver of all: Responding to Needs of Others and Self. CPRE Policy Briefs. Available online: https:/ / repository.upenn.edu/cpre_policybriefs/92 (accessed on 23 March 2021).

Argyropoulou, Eleftheria, Christina E. Syka, and Markos Papaioannou. 2021. School Leadership in Dire Straits: Fighting the Virus or Challenging the Consequences? International Studies in Educational Administration 49: 18-27. Available online: https://www. academia.edu/44571628/School_Leadership_in_Dire_Straits_Fighting_the_Virus_or_Challenging_the_Consequences (accessed on 12 February 2021).

Boyatzis, Richard E. 1998. Transforming Qualitative Information: Thematic Analysis and Code Development. Thousand Oaks: Sage.

Brackett, Mark, and Christina Cipriano. 2020. Teachers Are Anxious and Overwhelmed. They Need SEL Now More than Ever. EdSurge. Available online: https:/ / www.edsurge.com/news/2020-04-07-teachers-are-anxious-and-overwhelmed-they-need-sel-nowmore-than-ever (accessed on 20 March 2021).

Brackett, Mark, Mark Cannizzaro, and Scott Levy. 2020. The Pandemic's Toll on School Leaders Is Palpable. Here's What's Needed for a Successful School Year. EdSurge. Available online: https:/ / www.edsurge.com/news/2020-07-16-the-pandemic-s-toll-onschool-leaders-is-palpable-here-s-what-s-needed-for-a-successful-school-year (accessed on 20 March 2021).

Braun, Virginia, and Victoria Clarke. 2006. Using thematic analysis in psychology. Qualitative Research in Psychology 3: 77-101. [CrossRef]

British Psychological Society. 2020. Back to School: Using Psychological Perspectives to Support Re-Engagement and Recovery. Available online: https:/ / www.bps.org.uk/coronavirus-resources/public/back-to-school (accessed on 10 December 2020).

Crawford, Alison, Laura A. Currie, Beth Hannah, Jacqui Ward, and Imogen Wooton. 2020. Compassionate Transitions: Reconnecting School Communities Post-Covid-19 Closures. British Psychological Society. Available online: https:/ /discovery.dundee.ac.uk/ en/publications / compassionate-transitions-reconnecting-school-communities-post-co (accessed on 23 March 2021).

Dassiou, Xeni. 2015. Greece in Economic Crisis: The Case of Health and Education. Vierteljahrshefte zur Wirtschaftsforschung 84: 145-64. [CrossRef] 
Day, Christopher, and Pamela Sammons. 2014. Successful School Leadership. Educational Development Trust. Available online: https: / / www.educationdevelopmenttrust.com/EducationDevelopmentTrust/files/a3/a359e571-7033-41c7-8fe7-9ba60730082e.pdf (accessed on 23 March 2021).

Di Pietro, Giorgio, Federico Biagi, Patricia Costa, Zbigniew Karpiński, and Jacopo Mazza. 2020. The Likely Impact of COVID-19 on Education: Reflections Based on the Existing Literature and International Datasets. Luxembourg: Publications Office of the EU, Available online: https:/ / core.ac.uk/download/pdf/343468109.pdf (accessed on 5 January 2021).

Duffield, Sarah, and Dan O'Hare. 2020. Teacher resilience during coronavirus school closures. In British Psychological Society. Available online: https://www.leicestershire.gov.uk/sites/default/files/field/pdf/2020/4/17/BPS-Teacher-resilience-duringcoronavirus-school-closures.pdf (accessed on 13 January 2021).

Education Review Office. 2013. Stories of Resilience and Innovation in Schools and Early Childhood Services: Canterbury Earthquakes: 2010-2012. Available online: https:/ / ero.govt.nz/sites/default/ files/2021-05/Stories-of-Resilience-and-Innovation-in-Schoolsand-Early-Childhood-Services-Canterbury-Earthquakes-2010-2012-web.pdf (accessed on 2 March 2021).

Educational Institute of Scotland. 2020. Teaching during the Covid-19 Shutdown. Available online: https://www.eis.org.uk/Content/ images / corona/SurveyResults.pdf (accessed on 3 February 2021).

Evangelou, Maria, Brenda Taggart, Kathy Sylva, Edward Melhuish, Pam Sammons, and Iram Siraj-Blatchford. 2008. What Makes a Successful Transition from Primary to Secondary School? Effective Pre-School, Primary and Secondary Education 3-14 Project (EPPSE 3-14). London: Department for Children, Schools and Families. Available online: https://dera.ioe.ac.uk/8618/1/DCSF-RR019.pdf (accessed on 14 December 2020).

Feeney, Brooke C., and Nancy L. Collins. 2015. A new look at social support: A theoretical perspective on thriving through relationships. Personality and Social Psychology Review 19: 113-47. [CrossRef]

Fegert, Jörg M., Benedetto Vitiello, Paul L. Plener, and Vera Clemens. 2020. Challenges and burden of the Coronavirus 2019 (CO VID-19) pandemic for child and adolescent mental health: A narrative review to highlight clinical and research needs in the acute phase and the long return to normality. Child and Adolescent Psychiatry and Mental Health 14. [CrossRef] [PubMed]

Fereday, Jennifer, and Eimear Muir-Cochrane. 2006. Demonstrating Rigor Using Thematic Analysis: A Hybrid Approach of Inductive and Deductive Coding and Theme Development. International Journal of Qualitative Methods 5: 80-92. [CrossRef]

Galea, Sandro, Raina M. Merchant, and Nicole Lurie. 2020. The Mental Health Consequences of COVID-19 and Physical Distancing: The Need for Prevention and Early Intervention. Journal of the American Medical Association Internal Medicine 180: 817-18. [CrossRef]

Graham-Harrison, E., Angela Giuffrida, Helena Smith, and Liz Ford. 2020. Lockdowns around the World Bring Rise in Domestic Violence. The Guardian. March 28. Available online: https: / / www.theguardian.com/society /2020/mar/28/lockdowns-worldrise-domestic-violence (accessed on 2 February 2021).

Green, Jennifer G., and Elizabeth Bettini. 2020. Addressing Teacher Mental Health during the COVID-19 Pandemic. Teachers College Record. Available online: https://www.researchgate.net/publication/343360704_Addressing_Teacher_Mental_Health_during_ the_COVID-19_Pandemic/link/5f2ac16f299bf13404a3e1fb / download (accessed on 23 March 2021).

Gruber, June, Mitchell J. Prinstein, Jonathan S. Abramowitz, Anne M. Albano, Amelia Aldao, Jessica Borelli, Tammy Chung, Lee A. Clark, Joanne Davila, Erika E. Forbes, and et al. 2020. Mental Health and Clinical Psychological Science in the Time of COVID-19: Challenges, Opportunities, and a Call to Action. PsyArXiv. [CrossRef]

Halladay Goldman, Jane, Laura Danna, Jenifer W. Maze, Isaiah B. Pickens, and George S. Ake. 2020. Trauma Informed School Strategies during COVID-19. Los Angeles and Durham: National Center for Child Traumatic Stress. Available online: https://www.nctsn. org/sites/default/files/resources/resource-guide/trauma_informed_school_strategies_during_covid-19.pdf (accessed on 13 March 2021).

Hatzichristou, Chryse, Theodora Yfanti, Aikaterini Lampropoulou, Panagiotis Lianos, Georgios Georgouleas, Danae Athanasiou, Diamanto Fragiadaki, and Spyridoula Mihou. 2020. Return to the School and Fostering Psychological Resilience after the Stay-at-Home Period of the COVID-19 Pandemic: Useful Tips and Activity Worksheets. Athens: UOA Laboratory of School Psychology. Available online: http:/ / www.centerschoolpsych.psych.uoa.gr/index.php/2020-05-09-17-58-14 (accessed on 5 February 2021).

Heifetz, Ronald A., Alexander Grashow, and Marty Linsky. 2009. The Practice of Adaptive Leadership: Tools and Tactics for Changing Your Organization and the World. Brighton: Harvard Business Press.

Hubbard, Lea, Hollie Mackey, and Jonathan A. Supovitz. 2020. District Response to the COVID-19 Pandemic. CPRE Policy Briefs. Available online: https:// repository.upenn.edu/cpre_policybriefs/ 88 (accessed on 23 March 2021).

Kaul, Maya, Bryan A. VanGronigen, and Nicole S. Simon. 2020. Calm during crisis: School principal approaches to crisis management during the COVID-19 pandemic. CPRE Policy Briefs. Available online: https://repository.upenn.edu/cpre_policybriefs/89 (accessed on 23 March 2021).

Klipker, Kathrin, Franz Baumgarten, Kristin Göbel, Thomas Lampert, and Heike Hölling. 2018. Mental health problems in children and adolescents in Germany. Results of the cross-sectional KiGGS Wave 2 study and trends. Journal of Health Monitoring 3: 34-41. Available online: https:/ / www.rki.de/EN/Content/Health_Monitoring/Health_Reporting/GBEDownloadsJ/FactSheets_en/ JoHM_03_2018_Mental_Health_Problems_KiGGS-Wave2.pdf?_blob=publicationFile (accessed on 18 January 2021).

Lifelong Learning Platform. 2020. COVID-19: Mental Health and Wellbeing of All Learners Come First. Available online: http: / /11lplatform.eu/111/wp-content/uploads/2020/12/LLLP-Statement-COVID-19_EMDR-update.pdf (accessed on 2 March 2021). 
Liu, Cindy H., and Stacey N. Doan. 2020. Psychosocial Stress Contagion in Children and Families during the COVID-19 Pandemic. Clinical Pediatrics 59: 853-55. [CrossRef]

Liu, Shuai, Lulu Yang, Chenxi Zhang, Yu-Tao Xiang, Zhongchun Liu, Shaohua Hu, and Bin Zhang. 2020. Online mental health services in China during the COVID-19 outbreak. The Lancet Psychiatry 7: 17-18. [CrossRef]

Mahase, Elisabeth. 2020. Covid-19: Mental health consequences of pandemic need urgent research, paper advises. BMJ 369: m1515. Available online: https:/ / pubmed.ncbi.nlm.nih.gov/32299806/ (accessed on 21 February 2021). [CrossRef]

McLean, Leigh, and Karol M. Connor. 2018. Relations between third grade teachers' depressive symptoms and their feedback to students, with implications for student mathematics achievement. School Psychology Quarterly 33: 272-82. [CrossRef]

Neria, Yuval, Arijit Nandi, and Sandro Galea. 2008. Post-traumatic stress disorder following disasters: A systematic review. Psychological Medicine 38: 467-80. [CrossRef]

Paleologou, Mina P., Dimitrios C. Anagnostopoulos, Helen Lazaratou, Marina Economou, Lily E. Peppou, and Melpomeni Malliori. 2018. Adolescents' mental health during the financial crisis in Greece: The first epidemiological data. Psychiatrike Psychiatriki 29: 271-74. [CrossRef] [PubMed]

PeConga, Emma K., Gabrialle M. Gauthier, Ash Holloway, Rosemary S. W. Walker, Peter L. Rosencrans, Lori A. Zoellner, and Michele Bedard-Gilligan. 2020. Resilience is spreading: Mental health within the COVID-19 pandemic. Psychological Trauma: Theory, Research, Practice, and Policy 12: S47-S48. [CrossRef] [PubMed]

Policy Scotland. 2020. Children's Neighbourhoods Scotland-Early Insights into the COVID-19 Response-24 April 2020. Available online: https:/ / policyscotland.gla.ac.uk/cns-early-insights-into-the-covid-19-response-24-april-2020 (accessed on 23 March 2021).

Ryan, Richard M., and Edward L. Deci. 2000. Self-determination theory and the facilitation of intrinsic motivation, social development and well-being. American Psychologist 55: 68-78. [CrossRef]

Schneider, William, Jane Waldfogel, and Jeanne Brooks-Gunn. 2017. The Great Recession and risk for child abuse and neglect. Children and Youth Services Review 72: 71-81. [CrossRef]

Shultz, James M., Janice L. Cooper, Florence Baingana, Maria A. Oquendo, Zelde Espinel, Benjamin M. Althouse, Luis Herns Marcelin, Sherry Towers, Maria Espinola, Clyde B. McCoy, and et al. 2016. The Role of Fear-Related Behaviors in the 2013-2016 West Africa Ebola Virus Disease Outbreak. Current Psychiatry Reports 18: 104. [CrossRef]

Stone-Johnson, Corrie, and Jennie M. Weiner. 2020. Principal professionalism in the time of COVID-19. Journal of Professional Capital and Community 5: 367-74. [CrossRef]

Teach for America. 2020. Tackling COVID-19 Fatigue as a Teacher. How Educators Can Build Resilience amid the Pandemic. Available online: https: / / www.teachforamerica.org/stories/tackling-covid-19-fatigue-as-a-teacher (accessed on 5 February 2021).

UNISEF. 2020. COVID-19: Integration of Child Protection in Return to School. Tips for Teachers and School Management. Available online: http:/ / www.end-violence.org/sites/default/ files/2020-06/tips.pdf (accessed on 20 January 2021).

United Nations. 2020. Policy Brief: Education during COVID-19 and Beyond. Available online: https://unsdg.un.org/sites/default/ files/2020-08/sg_policy_brief_covid-19_and_education_august_2020.pdf (accessed on 3 March 2021).

Van Bortel, Tine, Anoma Basnayake, Faton Wurie, Musu Jambai, Alimamy S. Koroma, Andrew T. Muana, Katrina Hann, Julian Eaton, Steven Martin, and Laura B. Nellums. 2016. Psychosocial effects of an Ebola outbreak at individual, community and international levels. Bulletin of the World Health Organization 94: 210-14. [CrossRef]

Vlados, Charis. 2020a. Development and underdevelopment from the perspective of evolutionary socioeconomics in the post-COVID19 era. Journal of Economic and Social Thought 7: 181-212. Available online: https:/ / ssrn.com/abstract=3766763 (accessed on 20 March 2021).

Vlados, Charis. 2020b. The growth and development analytical controversies in economic science: A reassessment for the post-Covid-19 era. Journal of Economics and Political Economy 7: 209-33. Available online: http://kspjournals.org/index.php/JEPE/article/view / 2140 (accessed on 20 March 2021). 